\title{
The Wadden Sea Region: Towards a science for sustainable development
}

\author{
Pavel Kabat ${ }^{\mathrm{a}, \mathrm{e}}$, Jos Bazelmans ${ }^{\mathrm{a}, \mathrm{f}}$, Jouke van Dijk ${ }^{\mathrm{a}, \mathrm{g}}$, Peter M.J. Herman ${ }^{\mathrm{a}}$, Tim van Oijen ${ }^{\mathrm{a}, *}$, \\ Morten Pejrup $^{b}$, Karsten Reise ${ }^{c}$, Hessel Speelman ${ }^{a}$, Wim J. Wolff ${ }^{d}$ \\ ${ }^{a}$ Wadden Academy-KNAW, Ruiterskwartier 121a, 8911 BS Leeuwarden, The Netherlands \\ ${ }^{\mathrm{b}}$ University of Copenhagen, Department of Geography and Geology, DK-1350 Copenhagen, Denmark \\ ${ }^{c}$ Alfred Wegener Institute for Polar and Marine Research (AWI), Wadden Sea Station Sylt, D-25992 List, Germany \\ d Marine Benthic Ecology and Evolution, University of Groningen, Nijenborg 4, NL-9747 AG Groningen, The Netherlands \\ e International Institute for Applied Systems Analysis, Schlossplatz 1, A-2361 Laxenburg, Austria \\ ${ }^{\mathrm{f}}$ Cultural Heritage Agency, Ministery of Education, Science and Culture, Smallepad 5, NL-3811 MG Amersfoort, The Netherlands \\ ${ }^{\mathrm{g}}$ University of Groningen, Faculty of Spatial Sciences, Department of Economic Geography, P.O. Box 800, NL-9700 AV Groningen, The Netherlands
}

\section{A R T I C L E I N F O}

Article history:

Available online 15 June 2012

\begin{abstract}
A B S T R A C T
The Wadden Sea is one of the largest intertidal areas in the world and has been designated as a UNESCO World Heritage Site in recognition of its unique natural features. Major changes in the morphology and ecology of the Wadden Sea over the past millennium resulted from increasing anthropogenic influences such as coastal protection, land claim from the sea and drainage of wetland for agriculture, exploitation of natural resources from hunting and fishing to the extraction of groundwater, gas and oil, industrialisation at port locations and tourism at the islands. A sustainable future can only be achieved if policy and management are backed by solid science. Many of the anticipated changes result from the upscaling of pressures on the Wadden Sea system. Economic globalization leads to upscaling of fisheries, tourism and industrial activities, and thus to changed pressures on space and nature. Climate change will lead to changes in hydrographic patterns, species distribution and possibly tourism; through sea-level rise it will put pressure on coastal protection and the extent of intertidal areas. Invasions of exotic species will transform the ecosystem. There are three major related challenges to management: 1 . Nature conservation in a changing system requires a focus on preservation of the values and not the state of the system; 2 . The adaptation of the management structure to the scale increase of the pressures, so that local and regional management becomes better nested in transregional and transnational governance structures; 3. Finally, the management approach needs to deal with increasing uncertainty in external forcing of the system, as well as with nonlinearities in system dynamics when it is pushed outside its normal range of operation. Based on these pressures and management challenges, we advocate an integrated social-ecological systems approach for the scientific study and the science-based management of the Wadden Sea Region. The essential characteristics of this approach are strong interdisciplinarity and a focus on aspects of scale and cumulative processes.
\end{abstract}

(c) 2012 Elsevier Ltd. All rights reserved.

\section{Introduction}

The Wadden Sea is one of the world's most valuable stretches of coastline. Since 2009 the Dutch and German parts have been designated a World Heritage Site (CWSS, 2008). The area presents the world's largest coherent intertidal flats: $4700 \mathrm{~km}^{2}$ emerge during low tide. Its ecosystem is characterized by a rich benthic fauna supporting millions of coastal birds visiting in the course of a year (Reise et al., 2010 and references therein). The Wadden Sea extends roughly $500 \mathrm{~km}$ along the southeast coast of the North Sea

\footnotetext{
* Corresponding author. Tel.: +3158 2339033.

E-mail address: tim.van.oijen@waddenacademie.knaw.nl (T. van Oijen).
}

from Den Helder in The Netherlands to Blåvands Huk in Denmark (Fig. 1). A large part of the intertidal area is sheltered by barrier islands and sand bars against the surf of the North Sea. The area counts 25 inhabited islands and several smaller vegetated islands and barren high sands. The total area of the islands is about $2000 \mathrm{~km}^{2}$ and the Wadden Sea itself covers about $8000 \mathrm{~km}^{2}$. Part of the mainland is included in what is defined as the Wadden Sea Region (see Fig. 1) which has one of the oldest and most complex cultural landscapes in Europe and has been inhabited for more than 5000 years (Knottnerus, 2005; Vollmer et al., 2001).

Traditionally, the Wadden Sea Region has been an important agricultural area. Tourism has achieved an important source of employment especially on the islands and some mainland port 


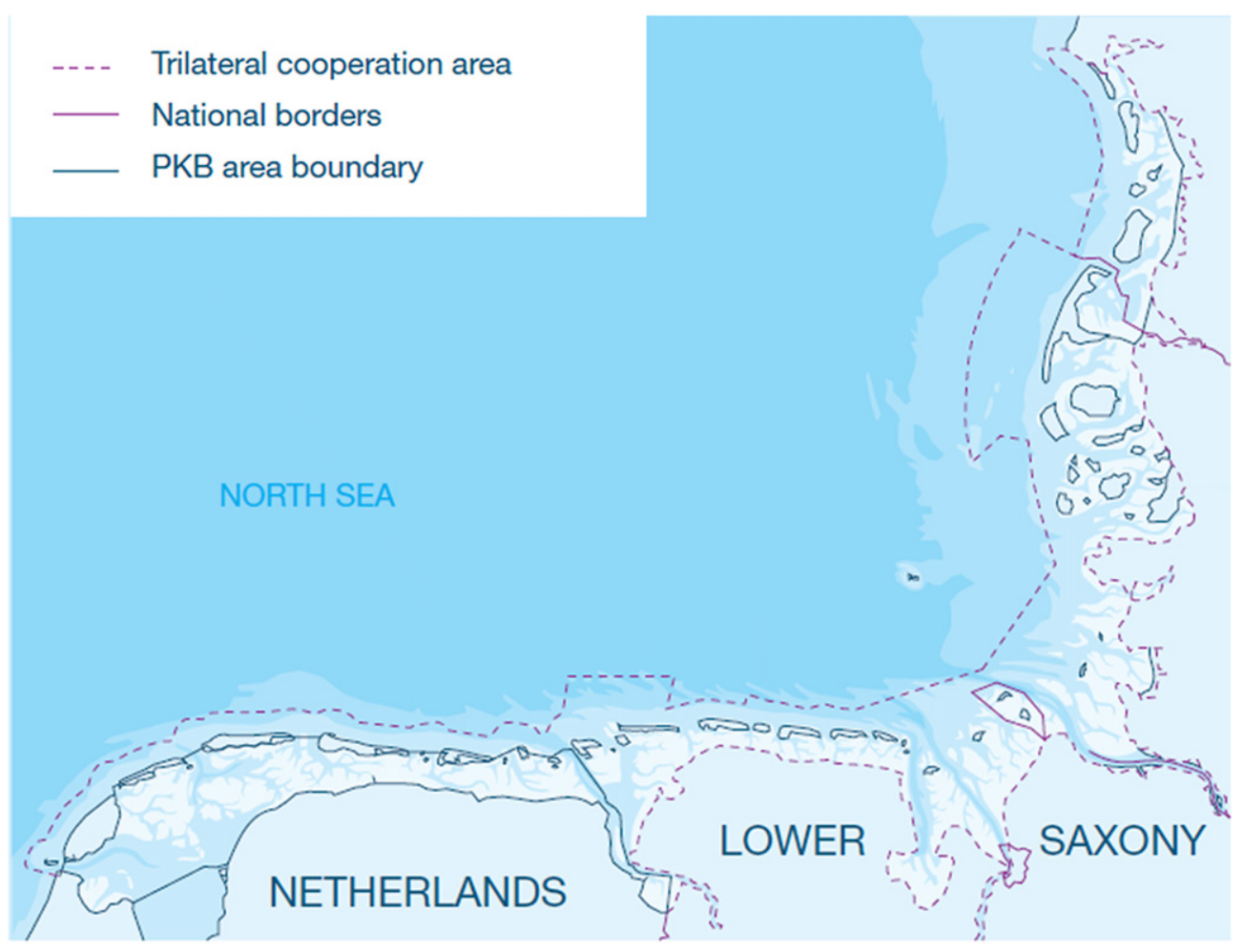

Fig. 1. The trilateral Wadden Sea Region.

localities (Sijtsma et al., in this volume). The major German ports of Hamburg, Bremen/Bremerhaven and Wilhelmshaven, the Dutch Eemshaven/Delfzijl and the Danish Esbjerg harbour important industries. At present, an estimated 3.5 million inhabitants live in the $17,500 \mathrm{~km}^{2}$ of land at less than $5 \mathrm{~m}$ above or even below mean sea-level in this region (CPSL, 2010). Knowledge about the past, present and future development and management of the nature, cultural heritage and the regional socio-economy of the Wadden Sea Region is of great interest for the future use of other coastal lowlands and extensive tidal zones all over the world.

The natural processes and socio-economic activities in the Wadden Sea Region form a complex interplay which we need to understand in order to achieve a solid, science-based management for a sustainable future of the region. In this paper, we advocate that an integrated approach is required to understand the Wadden Sea Region as a system in the short, medium and long term. In order to provide a background to the complexity of the combined natural, socio-economic and socio-cultural system, below we first analyse the development of the Wadden Sea Region from an exclusively naturally formed system towards a system that is the result of a combination of natural change and progressive anthropogenic influences. We then describe the major future challenges for this system. From these descriptions, we derive the essential components of an integrated system approach, and address the question how scientific research can best be organised in order to adequately inform the public and to support management.

\section{Natural and human history of the Wadden Sea Region}

Although the Wadden Sea Region is certainly not homogeneous in terms of nature and culture, the sub-regions do have an almost identical geological history and a shared history of human habitation. We present a chronological overview that shows the main patterns in the increasing human influence on the region. Interactions between the natural and the socio-economic system since the Wadden Sea came into existence are illustrated. We refer to Bazelmans et al. (in this volume) for a more elaborate review of the increasing human influence on the landscape of the Wadden Sea Region during the Holocene from a cultural-historical perspective. The geological evolution of the Wadden Sea during the Holocene period has been described in detail by Aagaard et al. (1995) (the Danish Wadden Sea); Bartholdy and Pejrup (1994); Chang et al. (2006) (the German Wadden Sea); Oost (1995); Streif (2004); Van der Spek and Beets (1992) and Vos and Van Kesteren (2000) (the Dutch Wadden Sea).

\subsection{The early development of the Wadden Sea Region after the last Ice Age}

Some 18,000 years ago, at the last glacial maximum, the sealevel in the region was about $125 \mathrm{~m}$ lower than it is today (Streif, 2004). In contrast with the previous Saale glaciation, the region was not covered with ice during this Weichselian glaciation. The Pleistocene landscape of the Wadden Sea Region has been formed both by glacial processes e.g. in the form of terminal moraines and by glaciofluvial processes e.g. in the form of outwash plains formed by the melting water from the Weichselian ice sheet. Some of the 16 present barrier islands have developed attached to local heights in the Pleistocene landscape. The islands Texel (The Netherlands), Amrum, Föhr and Sylt (Germany) have outcrops of Pleistocene sediments.

After the last Ice Age, melting of the Fennoscandian and Canadian ice shields caused the sea-level to rise rapidly. Initially, the rate of sea-level rise was too high to allow the formation of a barrier island system. Although there are some indications that the first barrier islands formed approximately 8000 years BP it was primarily when the rate of sea-level rise decreased to well below $10 \mathrm{~mm} / \mathrm{y}$ that the present-day landscape started to form (Streif, 2004). From 5000 BP the sea-level rise slowed to 1-2 mm per annum, and crustal adjustments in response to the unloading of the 
ice pressure in Scandinavia caused the land in the Wadden Sea Region to sink gradually by about $1 \mathrm{~mm}$ per year (Vink et al., 2007). At the start of the formation of the Wadden Sea system much of the sediment forming the Wadden Islands originated from the bottom of the newly inundated North Sea. In the later development of the barrier islands the longshore sediment transport also played an important role.

The main driver of coastal morphology has been the relation between sea-level rise and sediment supplied from the North Sea, until human engineering became more dominant towards the end of the last millennium (Fig. 2). This decreased the area of tidal flats by about one third, and the islands and the mainland coast line became increasingly protected against natural dynamics.

\subsection{Prehistory}

The landscape of the present North Sea basin has been inhabited by hunter-gatherers with a mobile lifestyle (Gaffney et al., 2009). When sea-level rose, these people had to give up the Doggerland and gradually retreated towards the present coastlines. There the terminal moraines of the mainland and of the islands of Sylt, Föhr and Amrum became densely populated by Neolithic people (Bantelmann, 1992; Behre, 2008). Several of their megalithic graves are still to be seen in this landscape. The occupation continued through the Bronze and Iron Ages.

The coastal area of the northern Netherlands had been colonised by people by the early Iron Age. Around 500 BC migrants from the sandy areas in the interior were able to settle in the salt marshes. Since then the region was populated by warlike agrarian tribes. In absolute terms, the population numbers were small, tens of thousands of people in total. However, compared with the sandy hinterlands, the population density was relatively high (De Mulder et al., 2003). In the more southern province of Drenthe the population density for the Iron Age en Roman period has been estimated at about 3 persons per $\mathrm{km}^{2}$; for parts of the northern province of Groningen at over 15 person per $\mathrm{km}^{2}$. In the course of the Iron Age and Roman Iron Age a complex settlement hierarchy developed of isolated farmsteads, hamlets and small villages (Knottnerus, 2005).

Dikes already were in use from 2200 to $2100 \mathrm{BP}$ but on a small scale (De Jonge, 2009). The area was still subject to regular flooding and thus, at first sight, a hostile environment. However, it offered
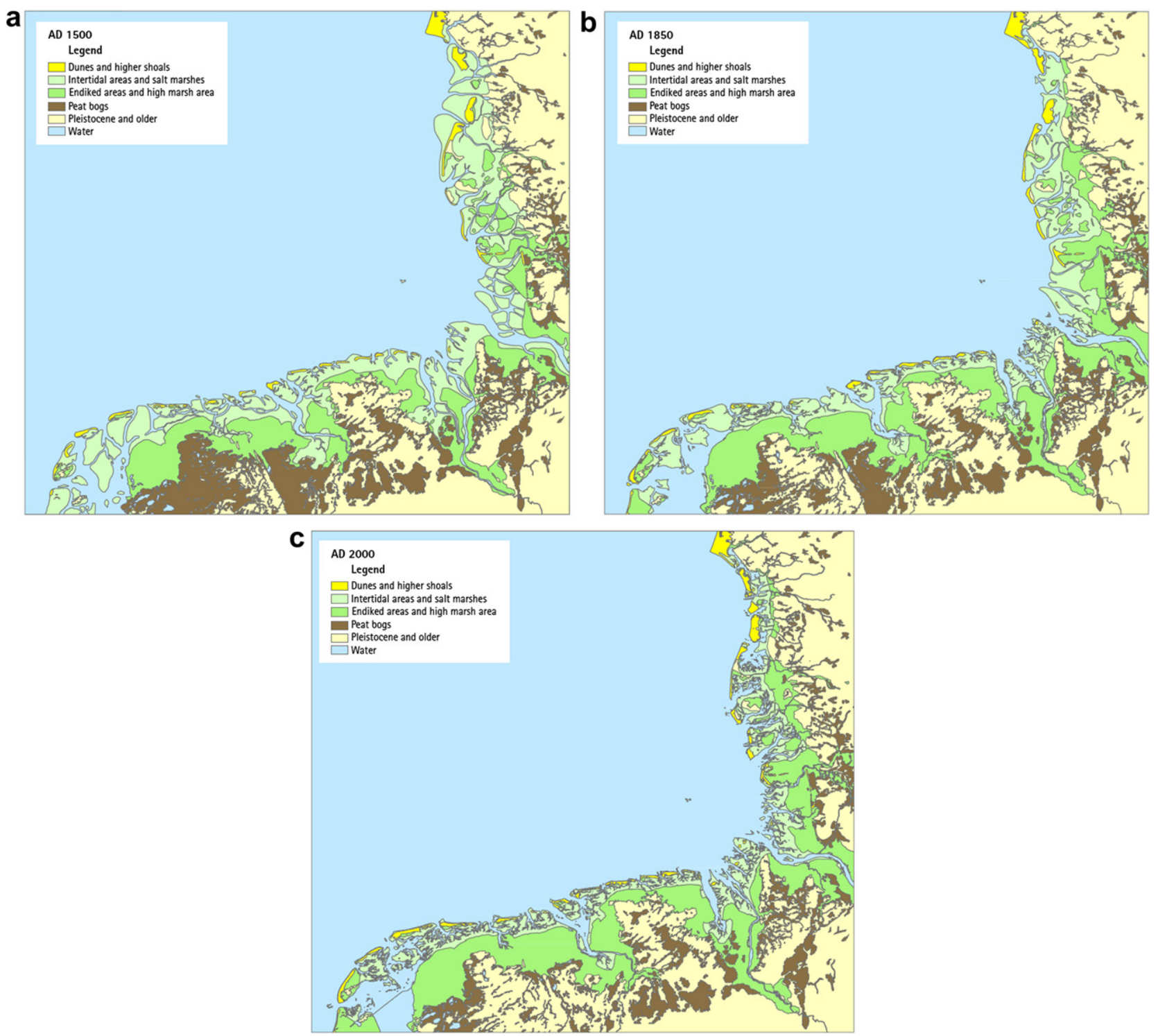

Fig. 2. The morphological development of the Wadden Sea since 1500, illustrated in three maps. a. 1500; b. 1850; c. 2000. Source: Wiersma et al., 2009. 
great opportunities in agricultural and economic terms, particularly for cattle-rearing. Permanent habitation was made possible by the construction of houses on podiums consisting of sods (terpen or wierden in Dutch; Warften or Wurten in German; værfter in Danish). Many of these mounds still can be found in today's landscape. Together with the agricultural activity, they were the first noticeable influence of man on the landscape. The humans living on the mounds also exploited the natural resources of the Wadden Sea Region by fishing and hunting (Lotze et al., 2005).

\subsection{Middle Ages}

In the first centuries of the Middles Ages (approx. 800-1500 $A D)$, the region came first under the sphere of influence and subsequently under the control of the Frankish and the Carolingian Empire. However, until the end of the 15th century, there was a substantial degree of socio-political fragmentation. Headmen [hoofdelingen] were in charge in the Frisian areas (the provinces of Noord-Holland, Friesland and Groningen in The Netherlands, and Ostfriesland and Nordfriesland in Germany). From the 9th century onwards, ecclesiastical institutions played a dominant role in local communities and in the design of the built environment and the landscape (see Bazelmans et al., in this volume).

The introduction of dike building and land reclamations resulted in large-scale loss of salt, brackish and freshwater marshes and only small strips of salt marshes remaining along the shores of the Wadden Sea. This changed the hydraulics and related processes as water transport and erosion and sedimentation patterns in the Wadden Sea (Reise, 2005). The first large-scale dike building activities commenced during the High Middle Ages, from the 11th to the 13 th century. This marked a significant change in the relationship between man and nature. Whereas previously the sea flowed freely over the whole region during storm tides, it was now shut out. This provided an enormous boost to habitation and agriculture but when storm surges broke through dykes, people and cattle drowned in high numbers. These disasters were perceived as God's aversion towards human wealth and corruption of moral standards, and had a lasting imprint on the mentality of the coastal population (Jakubowski-Tiessen, 2011).

Next to the building of dykes, the large-scale exploitation of the extensive peat lands between the clay areas and the sandy areas in the High Middle Ages also had a major impact on the coastal environment. In terms of water management, the construction of dykes and the exploitation of the peatlands cannot be considered separately (De Jonge, 2009). The exploitation together with the oxidising of the peat caused lowering of the level of the mainland behind the dykes which became a permanent challenge for drainage. Salt and peat mining also substantially contributed to the lowering of the marsh surface below the level of the sea.

The intensified use of natural resources through the commercialisation of fisheries and hunting was leading in several cases to changes in the ecosystems, principally through extinction of exploited species. For example, in this period, grey seals were extirpated from the Wadden Sea (Wolff, 2000).

\subsection{Early modern era}

The demographic changes in the 9th to the 14th century have formed the basis for radical developments in the areas of economics, politics and religion during the early modern era. Although the region was familiar with a modest farm production for an urban market, the 15th and 16th centuries witnessed the development of market-oriented agricultural production, agricultural specialisation and urban growth. This resulted in an economic boom with intensive participation in international trade and shipping. The many ship remains in the Wadden Sea bear witness to this phenomenon. In socio-political terms, people in the region adapted themselves to a central power and different social classes became established (see Bazelmans et al., in this volume).

While agriculture on the mainland prospered, islanders often turned to whaling in Arctic waters since the 17th century. From some islands almost all males left in spring to embark for whaling, leaving the island's agriculture and artisanal fishing for the rest of the year to the women. Although whaling was accompanied by a high death toll, it also accumulated considerable wealth which is still manifested in the proper houses built by commanders. When catch rates declined in the 18 th century, whalers switched to trading vessels sailing across all oceans.

From about 1000 to $1200 \mathrm{AD}$ until about 1900 the nature of the interaction between humans and the Wadden Sea natural system showed only gradual changes. Coastal salt marshes were reclaimed continuously although the amount during different periods varied because of economic and societal conditions. The tidal landscape was exploited intensively by fishermen and hunters with consequences for the size of animal populations of fish, shellfish, seals and birds (Lotze et al., 2005). Regulation of human activities was almost non-existent, although in later years a licence was needed for reclamation of salt marshes and the harvesting of eelgrass in the Dutch Wadden Sea. In this gradually-changing relation between humans and the Wadden Sea, some events stand out like the plague of the shipworm (Teredo navalis) in 1730-1732, which led to the replacement of wooden piles in the seawalls by stone protection, and stopped the use of eelgrass as building material in dykes (Bakker, 2011; Van der Meer, 2009; Van Katwijk, 2003).

\subsection{The modern and present era}

In the course of the 19th century, agriculture in the region underwent substantial changes and a form of agricultural capitalism arose which had a major impact on society. Arable land and pasture was concentrated in the hands of large-scale farmers [hereboeren] who employed large numbers of agricultural workers. Social inequality was a key feature of the modern era and existed well into the 20th century. Middle-class elites played a key role in reconciling provincial self-confidence with loyalty to the respective state, the Netherlands, Germany and Denmark. In addition to a wide range of religious denominations, various sections of the population developed ideological perspectives in which research, progress, edification and development played a key role (see Bazelmans et al., this volume).

Of essential importance for the most recent history is the transition made in the middle of the 20th century from a situation of scarcity for many to one of abundance for many. Although there was no large-scale industrialisation or urbanisation in the region, the progressive mechanisation process enabled its inhabitants to choose a quite different relationship with their natural environment and landscape. Rationalisation and economy of scale are the key terms used to describe the trends in agriculture, the design of the built environment and the infrastructure. On the islands, tourism advanced to the key economy and also considerably changed the life style of the islanders. New machines based on the use of fossil energy greatly facilitated the embankment of salt marshes and now also included tidal flat systems. The largest of all projects was the separation of the Zuiderzee (now IJsselmeer) from the Wadden Sea in 1932 by the Afsluitdijk to improve coastal protection and to gain agricultural land. This changed the ecosystem of the estuary completely and reduced the populations of diadromous fish (De Beaufort, 1954). The islands of Sylt and Rømø became connected with causeways to the mainland in 1927 and 1943, respectively. Following severe storm flood disasters in 
the Dutch delta area in 1953 and in Hamburg 1962, governments have launched an unprecedented program of coastal defence.

As a corollary, people behind the dykes began to feel safe. This may have been an essential prerequisite for a shift in perception from a threatening sea to one that has become more and more threatened by human impacts and consequently deserves protection as well (Fischer, 2011). The almost one thousand year old tradition of reclaiming land from the sea for agriculture slowly died in the second half of the 20th century because nature values were higher valued than economic gains (Wolff, 1992). Due to the excellent and visionary work of the Mazure committee plans for the total embankment of the former Zuiderzee and the Wadden Sea with dams between barrier islands and across estuaries were given up (report Waddenzeecommissie, 1974). Cost-benefit-analysis showed that reclaiming the land was also not profitable from pure economic point of view (Oosterhaven, 1981). Also in Germany land reclamation for coastal protection came to an end in the 1980s.

While land reclamation was cancelled there were growing concerns about the impacts of other human activities: fishery, hunting, military exercises, coastal protection, tourism and industrial developments. It led to the implementation of many policy measures that protect the ecological values of the region (see next section). In the 2000s the discourse shifted from nature protection towards a discourse where nature development could go hand-inhand with sustainable economic development (Runhaar et al., 2009; Reise, 2011). The turning point was the report of the Advisory Group on Wadden Sea Policy (Meijer Committee) published in 2004 that noted that policy on and management of the Dutch Wadden Sea had reached an impasse and that the natural qualities of this unique region had deteriorated in a number of respects. However, the committee also found that a defencive policy and management style had been adopted with respect to the Wadden Sea Region, in which all the energy had been focused on prevention rather than creation and development. The committee felt that a major unintended consequence of this was that the development and improvement of the natural environment had been impeded and the economic development of the Wadden Sea Region and the northern part of the Netherlands had been blocked. The committee therefore argued strongly in favour of adopting an offensive conservation strategy. According to the committee, the main objective was to design a sustainable means of protecting and developing the Wadden Sea as a nature reserve and preserve the unique open landscape. The committee believed that an integrated perspective based on prioritising the natural environment with limited shared human use was necessary to monitor and continue to develop the values and interests which are at issue. The offensive strategy that the committee envisaged included establishment of a Wadden Fund to finance additional investment in a sustainable future for the Wadden Sea Region. As a consequence of the report of this committee it was allowed to extract natural gas from beneath the Wadden Sea under the condition of strictly monitoring of the effect on the level of the Wadden Sea bed ('hand aan de kraan' principle). Parts of the revenues of natural gas were used to establish the proposed Wadden Fund with a budget of 800 million euro available over for period of 20 years (including compensation for cockle fishers). The development of the awareness of the natural values in combination with the need of sustainable regional economic development of the Wadden Sea Region during this time period constitutes a major mind shift in the public opinion.

\section{The dawn of nature protection in the Wadden Sea}

Fifty years ago, a gradual mind shift commenced in the public perception of the Wadden Sea from an intertidal wasteland from an agricultural perspective and an often threatening stormy sea towards a natural wetland of global importance and towards a sea threatened by pollution and other human impacts (Wolff, 1992). This mental transition was accompanied by conflicts between coastal stakeholders and mostly urban nature conservationists. This prompted the Danish, German and Dutch governments to begin cooperation on nature conservation and environmental monitoring. This has so far culminated in the nomination of the Dutch and German sectors of the Wadden Sea as World Heritage Sites based on their universally outstanding hydrography, morphology, ecology and biodiversity (CWSS, 2008). Below some steps in the development of this new perception of the Wadden Sea are described.

\subsection{The first protection measures}

In the first decade of the 20th century the idea of nature protection which had developed on land in the second half of the 19th century, was introduced into the Wadden Sea. In the period 1907-1916 the small islands of Jordsand (1907), Memmert (1907), Norderoog (1909), Mellum (1912) and Griend (1916) obtained protected status because of their large breeding colonies of seabirds. Egg collecting and hunting of adult birds were not longer allowed. Remarkable enough the protection of breeding colonies was seen as sufficient; the protection of tidal flats and shallow waters was not considered necessary.

Due to initiatives of artists on the island of Sylt, a dune area and nearby cliff with a tricolour of tertiary deposits became the largest nature reserve of Germany in 1923. Rather than for the protection of rare plants and animals, the intention was to preserve the sublime nature of this coastal landscape inspiring many painters and writers. However, these reserves remained singular examples of nature conservation. In the first half of the 20th century, the Wadden Sea as such was not yet seen as a natural entity but as a coast of dreary mudflats and treacherous to sail. Early tourists remained concentrated at health resorts and the fronting beaches.

\subsection{Awareness of the Wadden Sea as a rich and threatened coastal wetland}

In the 1960s the significance of the Wadden Sea with its barrier islands, tidal flats, salt marshes and sand dunes became more and more apparent to ecologists. The International Waterfowl and Wetlands Research Bureau (IWRB) and other organisations made inventories of wetlands on a European scale and initiated bird counts. The results were presented at international conferences among which the MAR conference held in the Camargue in 1962 has to be viewed as an outstanding event. For the first time the Wadden Sea and other European (and North African) wetlands could be compared and thus the outstanding position of the Wadden Sea as a breeding and feeding area for coastal birds became clear to European scientists and conservationists.

With growing awareness of the natural values, several human activities within the Wadden Sea became a concern, i.e., land reclamation and salt marsh management, fishery, hunting, military exercises, coastal protection, tourism and industrial developments.

In 1962 Rachel Carson's book Silent spring was published, showing how chemical pollutants could affect the animal populations of entire landscapes (Carson, 1962). Dutch hydrographers knew that the residual current along the Dutch coast carried the discharge of the River Rhinetowards the Wadden Sea (e.g. van Veen, 1936). The death around 1965 of tens of thousands of seabirds in the Dutch Wadden Sea, among which spoonbill, sandwich tern, eider duck and herring gull, made clear that pesticide pollution from the petro-chemical industries at the Rhine estuary could influence the Wadden Sea ecosystem. In the same period it 
was noted that in the Dutch Wadden Sea the numbers of harbour seals declined due to an at that time unknown cause. In March 1967 the super tanker Torrey Canyon carrying 120,000 tons of crude oil, ran aground on the coast of Cornwall, U.K. This disaster was covered extensively by the public media and nature conservationists realized that a similar disaster could happen to the Wadden Sea.

This resulted in private initiatives to strive for better protection of the Wadden Sea. An international (NL, D, DK) working group of concerned scientists was established in 1965. They published a scientific overview of the geomorphology, hydrography and ecology in a series of 11 reports, collectively known as "The ecology of the Wadden Sea" (Wolff, 1983). The aim was to inform the public about recent research results showing the unique position of the Wadden Sea. Many of these scientists also took part in other initiatives. Their most influential outreach was their contribution to a lavishly illustrated book on the Dutch, German and Danish Wadden Sea with its natural values and threats published by the Wadden Sea society and Natuurmonumenten (Abrahamse et al., 1976). A school boy, Kees Wevers, had started this Landelijke Vereniging tot Behoud van de Waddenzee [National Society for the Preservation of the Wadden Sea], also in 1965 . This society developed into a highly influential non-governmental organisation. In Germany, among others Gerd Oetken founded the Schutzstation Wattenmeer in 1962 which established visitor centres on many islands and offered tours into the mudflats guided by young volunteers. In Denmark, an NGO group for the protection of the Wadden Sea was formed in which scientists, managers and different stakeholders were represented.

Such initiatives were pushed by a policy document of the Dutch government in 1967 which proposed to reclaim the Wadden Sea. After public discussion this led to the establishment in 1970 of a government committee (called Commissie Mazure after the name of its chairman) charged with the task to investigate the best options for the future of the Dutch Wadden Sea. In 1974, the Mazure committee concluded that the Dutch Wadden Sea should not be reclaimed and instead be protected as a nature reserve or national park (report Waddenzeecommissie, 1974). The Dutch government accepted the conclusion and formulated a Wadden Sea policy in a document known as the Planning Decision Wadden Sea under the Dutch Planning Act and which stated that "the protection, the preservation and where needed the restoration of the Wadden Sea as a nature area" (de bescherming, het behoud en waar nodig het herstel van de Waddenzee als natuurgebied) should be the target of the Dutch government policy. In 1980 the Dutch Parliament agreed with this policy and in 1981 major parts of the Wadden Sea were protected as "state nature reserves". In Germany, almost the entire Wadden Sea became a National Park (Schleswig-Holstein in 1985, Niedersachsen in 1986), but excluded were the large estuaries and most of the islands. Also the Danish Wadden Sea received protected status and the peninsula Skallingen was taken over by the Danish authorities in 1979 to decrease grazing and prevent further building of summer houses. At the same time a protected area between Skallingen and the island Langli in the Wadden Sea was established as a "natural scientific reference area". All the above examples show the growing awareness of the Wadden Sea as an endangered coastal wetland during the 1960s and 1970s.

\subsection{Towards a trilateral Wadden Sea cooperation}

Already in 1974 the Dutch government had consulted the Federal Republic of Germany and Denmark about international cooperation in Wadden Sea protection. These consultations shipwrecked due to disagreement between the federal and the regional state governments in Germany. To solve the problem it was agreed that scientists of the three countries should investigate the matter and report on the desirability of international Wadden Sea protection. A meeting was held at the Dutch island of Schiermonnikoog in November 1975 (Wolff, 1976). Later, this meeting was considered to be the first International Scientific Wadden Sea Symposium. The meeting reported positively on international Wadden Sea protection so the process could continue.

Since 1978, The Netherlands, Denmark and Germany have been working together on the protection and conservation of the Wadden Sea covering management, monitoring and research, as well as political matters. In 1982, a Joint Declaration on the Protection of the Wadden Sea was agreed upon in which the countries declared their intention to coordinate their activities and measures for the protection of the Wadden Sea. To facilitate the cooperation in nature management, a Common Wadden Sea Secretariat was established in Wilhelmshaven in 1987. Regular scientific symposia were organized, ecosystem studies at selected tidal basins were conducted, and the Trilateral Monitoring and Assessment Program (TMAP) formed the basis for the Wadden Sea Quality Status Reports since 1991. In 1997, a Trilateral Wadden Sea Plan was adopted which defines common management targets and which has been updated in 2010 (CWSS, 1998, 2010).

\subsection{Nomination as a World Heritage Site}

Although the Wadden Sea area was listed as a biosphere reserves in the 1980s and was subject to protection by several international conventions concerned with the natural environment, the highest level of international recognition was attained with the nomination of the Dutch and German Wadden Sea sectors as a World Heritage Site in 2009 (an extension to the Danish part is envisioned for 2013). On a global scale, up to now 43 other coastal sites are listed by the UNESCO as natural World Heritage, among them the Sundarbans (India and Bangladesh), the Everglades (USA), the Galapagos Islands (Ecuador) and the Great Barrier Reef (Australia). While nature protection in the Wadden Sea has met considerable opposition by local stakeholders in the past, the World Heritage is now widely appreciated (Van der Aa et al., 2004).

Roughly within half a century, a complete mind shift has taken place from a coastal region struck by a threatening stormy North Sea and burdened by a fuzzy fringe of salt marshes, mudflats and shifting sands before the 1960 s, to a well protected and globally outstanding coastal wetland at the beginning of the 2000s. Natural values have advanced to the economic basis of the Wadden Sea Region, attracting more than 10 million touristic visitors per year.

\section{Future challenges for the management of the Wadden Sea Region}

As shown in the previous section, the protected status of the Wadden Sea, both nationally in the three countries and internationally in the trilateral agreement, has been formalized in legislation and different management institutions. Over time, this has also evolved from a static and defencive (purely 'conservation') strategy, towards a more dynamic and positive strategy aiming at sustainable development. Over the last decade, we have moreover witnessed the installation and operation of the European Natura 2000 legislation. This has led to significant changes, e.g. in fisheries management. In The Netherlands, the cockle fisheries debate was crucial in this discussion and in the development of legislation realizing the precautionary principle (Turnhout, 2008; Van Nieuwaal, 2011). New challenges arise in realizing initiatives to restore natural values, as in the Programma naar een Rijke Waddenzee (www.rijkewaddenzee.nl). In this Dutch programme, NGO's and government bodies cooperate in a coordinated move to improve natural quality by better management of the physical 
infrastructure, fisheries, sea defences and other exploitation. The programme also explicitly aims at a scientific underpinning of these initiatives.

In the present paper we want to look ahead and analyse the need for scientific underpinning of management at a decadal time scale. Whereas the number of different issues arising in the Wadden Sea management can easily lead to ad hoc, sectoral approaches, it is also important to keep the general picture and prepare the scientific understanding needed for future major issues in management. We argue that the scale difference in driving forces, from local/national to regional/global, is the central challenge that needs to be taken into account for the management of the area. This global dimension is reflected both in the pressures on the system, as well as in its protection status. It is also present in the role the Wadden Sea can play as a globally relevant example of sustainable coastal development.

In many respects, the relevant scales of the pressures on the system are becoming global. Global population number, welfare, consumption and production are increasing fast. Global trade and travel flows cause increasing pressures on natural systems on the global scale profoundly affecting coastal ecosystems. Because there is a tendency that people live more and more in big cities, economic, social and cultural globalization foster developments in the human society at the coastlines, e.g. related to transportation, harbour development and tourism, that change the context for local management. Adaptation of a democratic management system to these pressures, objectives and management responses at the appropriate scale in a world that is globalizing at a high rate, is the major challenge for the Wadden Sea Region in the new millennium. It is, however, not unique to this coastal system. Thanks to its World Heritage status, the Wadden Sea has become a relevant example and role model for challenges experienced by all management of regions with high natural values. The main pressures on the natural system of the Wadden Sea are described below.

\subsection{Climatic warming}

There is considerable uncertainty about the effects of climate change on the Wadden Sea. Global climate predictions (IPCC, 2007) inevitably show a wide range, but this uncertainty grows with downscaling to a relatively small region such as the Wadden Sea Region. Regional climate predictions have been made for the German North Sea coast (Von Storch and Claussen, 2011). They have also been prepared for the Dutch part of the Wadden Sea Region (Kabat et al., 2009b). Effects of climate change for the Wadden Sea Region will manifest themselves through a number of anticipated effects. Temperature increase and changes in the seasonal pattern will have effects on the ecosystem through the physiology of organisms which translates into changes in distribution patterns of species and interspecific relations (Beukema, 1992; Beukema et al., 1990, 2009; Beukema and Dekker, 2005; Philippart and Epping, 2009; Wiltshire et al., 2010). Temperature increase may also substantially benefit tourism.

\subsection{Rising Sea}

For the geomorphology, areal size of habitats and the safety of the inhabitants in the Wadden Sea region, an accelerating sea-level rise would no doubt be the strongest long-term driver (Wolff et al., 2010; CPSL, 2010). Basic questions arise. With a subsiding land on one side of the dikes and an accelerating sea-level rise on the other, what will be the long term adaptations which supersede the intermittent role of stronger and higher dikes? Could natural sedimentation still balance the rise in water in such a way that tidal flats and salt marshes will not become permanently submerged? Should eventually the strategy of stabilizing the positions of barrier islands be superseded by adapting island infrastructures and homes to islands which move and change shape in response to higher levels of the sea?

Global sea-level is linked to global temperature by thermal expansion and glacier ice loss. However, the future contributions from the polar ice sheets remain the largest uncertainty in projections of sea-level rise in this century and beyond (Willis and Church, 2012). Up to now, there is a good correspondence between a recent increase in global sea-level rise and the rise measured in the Wadden Sea (Kemp et al., 2011; Wahl et al., 2011), although in addition the glacio-isostatic subsidence has to be taken into account (Gehrels et al., 2006; Vink et al., 2007). For the purpose of contingency planning, the Dutch Delta Commission made a high-impact low-probability worst-case scenario. This scenario estimates that the relative sea-level may be about $1 \mathrm{~m}$ higher in 2100 (Samen werken met water, 2008). In any scenario, sea-level rise will put pressure on the safety of the inhabitants of the Wadden Sea Region. It is a threat for the economic activities in the region due to the risk of interruption in production or damage to real estate and infrastructure on the one hand and the cost of flood protection on the other hand.

Under high rates of sea-level rise and insufficient longshore or onshore sediment supply, barrier island systems experience sediment shortage, which under natural conditions causes the barrier island to move towards the mainland und displace their massive volume of sediment towards the tidal basin (FitzGerald et al., 2008). This is incompatible with a fixed position of the islands, and thus creates the need for alternative sediment sources (CPSL, 2010). Model explorations also suggest that at high rates of sea-level rise, the natural import of sediment into the tidal basins could be too low for the basins to continue adjusting to the level of the sea. The largest tidal basins are expected to face a negative sediment budget first. Substantial amounts of sand need to be dredged from the bottom of the North Sea to nourish the sandy islands and tidal basins with the aim to compensate for sea-level rise (Reise, 2003; CPSL, 2010). Dikes need to be adapted to elevated storm tides. However, the Wadden Sea coast is faced with an unsustainable development with a rising sea-level in front of a subsiding surface of the land in the marsh. The old tradition of building houses on dwelling mounds (terpen,Wurten, Warften) from the time before a coherent "golden ring" of dikes came into place may be revived for the Wadden Sea Region. Homes may be also built on floats to reduce the risk of flooding. Instead of draining deep lying land, a waterscape may be created where agricultural use gives way to aquacultures or recreational areas. Although this sounds futuristic, the debate on such alternative land use ideas should commence in an attempt to combine necessary adaptations to a continuing rise of the sea with novel economic potentials (Reise, 2011).

\subsection{Globalization of the biota}

As in other coastal regions with a long tradition of busy ports with trade relations across the oceans, there has been a cumulative process of alien species invasions into the Wadden Sea Region, penetrating the native species communities and occasionally even achieving dominance (Wolff, 2005; Buschbaum et al., in this volume). The rate at which new invasions are observed is increasing. However, most of the invasions did not result from direct introductions into the Wadden Sea. Immigrations occurred after initial introductions elsewhere along the European Atlantic coasts with more transoceanic commerce and aquaculture activities employing organisms from overseas.

It is suggested that 'old' invasions, such as Spartina-grass, Crepidula-limpets and an Australian barnacle show a new wave of expansion in the wake of climatic warming (Loebl et al., 2006; Nehls et al., 2006; Witte et al., 2010). Also the rapid invasion of 
Pacific oysters has been facilitated by summer temperatures above average (Diederich et al., 2005). This indicates a synergistic effect between climate change and invasion success in the Wadden Sea. Nonnative species have strongly pervaded the recipient ecosystem and the new interactions will permanently create novel and unique eco-evolutionary developments (Carroll, 2011). Although the cumulative process of species invasions is increasing species richness (Beukema and Dekker, 2011), such changes may not only alter ecosystem functioning but may affect fisheries and the touristic use of the Wadden Sea as well.

\subsection{Globalization of the economy}

Regional and national economies are becoming ever more closely interwoven because the specialisation of production processes is taking place on a global scale in locations where the greatest benefit can be derived from economies of scale or cost advantages. As a result, international trade and transport flows have increased and also affect the ports in the Wadden Sea Region because more and taller ships are used (Eurostat, 2012). Economic activities like fishing, agriculture and tourism are also subject to international competition and this may lead to changes in the production locations and scale and to other tourist destinations.

When deciding whether the Wadden Sea Region is a suitable location for the production or distribution of goods, it is essential to make an overall assessment from a trilateral perspective of the costs and benefits of alternative locations inside and outside the Wadden Sea. An example is the mechanical cockle fisheries that provoked considerable political struggle in The Netherlands in 2000-2005 (Van Nieuwaal, 2011 and references therein). The cockles were nearly all exported to southern European countries at the expense of damage to the ecosystem in the Wadden Sea (e.g. Piersma et al., 2001 but see the more multi-facetted discussion in Van Nieuwaal, 2011).

The power stations planned in the estuaries of the Wadden Sea (Ems estuary, Jadebusen, Elbe) are a good example of large-scale investments in the Wadden Sea Region that are beneficial especially outside the region and possibly have a highly negative environmental impact in the Wadden Sea due to the use of cooling water, the dredging of access channels to bring in coal and $\mathrm{CO}_{2}$ emissions. Pathways and cables towards offshore wind parks, and possibly pipelines for captured and fluidized $\mathrm{CO}_{2}$ for storage below the North Sea, will traverse the Wadden Sea. The planned wind parks seaward of the Wadden Sea are likely to attract further industrial developments in the offshore region. This thus leads to an additional challenge: how to match the economic activity nearby the Wadden Sea with the unique natural values of this area.

From a commercial point of view the power stations planned for Eemshaven are highly profitable for investors. But it is uncertain whether this is also true from a societal point of view when account is taken of the negative external impact in the form of environmental damage and a comparison is made with possible alternative and more sustainable development options for the trilateral Wadden Sea Region. Old problems with eutrophication, cooling water and chemical pollution will never get back to zero and continue to stress the ecosystem. Shipwrecking, lost containers and oil spills are also a potential threat to the ecosystem. In addition, increasing numbers of visitors could intensify coastal urbanization. This could, just like coastal defence, further the sprawl of hard shoreline structures where once soft and gentle shores prevailed.

\section{Challenges for management}

The trends sketched here have important consequences for the Wadden Sea management. Since human influence is so important to determine the system's fate and evolution, it is clear that the motivations for human behaviour, essentially the values of society, are among the most important drivers for the system. These values have been seen to be variable in history, and are constantly changing also in the present day. Moreover, as has been argued with respect to recent developments and prospects for the future, there is a competition of different value systems between inhabitants and visitors, national and international communities and also between the short and the long run. Thus, the political system and its way of division of power will be of great importance for the future of the region and the type of management that will be required and/or provided for the Wadden Sea Region in the coming decades. This is especially interesting against the background that now finally the Wadden Sea has been recognized as World Heritage Site and its conservation has been sanctioned by the international community. Another challenge is matching the spatial and time scales at which natural and socio-economic processes take place. A third consequence of the future trends is the decreasing predictability of the external forcing on the Wadden Sea system.

\subsection{Conservation of natural values in a changing system}

Change will be apparent in the ecological, geomorphologic, economic and social subsystems. It will also be translated into the landscape, e.g. due to clogging of the horizon or filling of (now) empty spaces. One of the major grounds to declare the Wadden Sea a World Heritage Site is the natural dynamics of the geomorphology (UNESCO, 2009) which now might become partially driven by anthropogenic climatic changes including sea-level rise and possibly altered storminess. This modification of these dynamics may come in direct conflict with safety of inhabitants or ecological functioning of the system. Conserving the system in its present state with the aid of (intensified) sand nourishments at the sandy coasts is highly unnatural, but yet may conserve the ecological values (e.g. migrating birds) and morphology in a 'better' state than a (naturally) drowned system. This is especially true if on a longer time scale a drowned system is unavoidable. Managing change in a conservation area, including strategies of reversal, mitigation or adaptation where most appropriate, will be a major challenge for the future.

Managing change implies that the unique values of the Wadden Sea, rather than its current state be as well preserved as possible. The ultimate aim of conservation politics could not be to conserve a particular, frozen, state of the natural system against all trends in the boundary conditions, such as climate, large-scale hydrography or species invasions. However, even when change may be inevitable, not every change is equally desirable. Conservation politics therefore must find a basis for management that is independent of the physical possibility to maintain a steady state in the system. This basis can be found by focussing on how the most important values can be maintained in a changing system. As mentioned in the introduction, in the case of the Wadden Sea, the migrating bird populations of world importance are one of the major values of society. Other values relate to the delicacy of coastal and estuarine geomorphological processes, and to the adventure of long wet walks across the bottom of the sea when the tide is out. Conservation politics should also take account of how the valuation itself changes over time. Valuation is, therefore, the result of a societal discussion process that will continue in the future. Science plays a crucial role in this discussion, as 'spokesperson of the inarticulate' (Latour, 2004), but also as a methodologically sound way of obtaining insight in the system, and thus of conserving consistency in the valuation and the management. Science is, however, not the exclusive source of 'truth' or the absolute benchmark for conservation policy, as this necessarily also relates to economic, social and 
legal domains of society, as well as to cultural and aesthetic norms. In this concept, scientific insight is in need of permanent improvement and actualisation, so as to serve and inform the community debate as well as possible. A lively and multidisciplinary scientific activity, including a lively discussion culture, are thus necessary conditions for the permanent actualisation of conservation policies.

\subsection{Matching scales}

A second consequence of the pressures on the Wadden Sea system concerns scale matches and mismatches both in time and space between the governance and the natural system. In the Wadden Sea Region, a fundamental change of scales has taken place and is still taking place for both systems. The social system, or at least the part of it where policy aims are set and evaluations are made, is upscaling by defining the entire Wadden Sea as a (managerial) unit, and by setting the objectives of the policy in the framework of conserving important natural assets at world scale as UNESCO World Heritage Site. The economic system is upscaling too because of worldwide specialization of production and equalizing consumption patterns together with negative environmental effects that may occur on a worldwide scale. At the same time, the natural system is subject to a number of global changes like climate change that can hardly be influenced (at most mitigated) at a local or regional level.

Because of global trends in the economy, there is an increasing need to evaluate projects on a larger scale than before. The power stations planned along the entire Wadden Sea are a good example of this need. When regulations require that location permits are evaluated based on the effects of individual plants, this may lead to suboptimal location choices when the cumulative effects of all newly planned power plants together exceed crucial thresholds for the ecosystem that are not violated by any of the individual plants. Cooling water intakes of the different plants do not normally interfere with respect to temperature increase of the water, but they do affect a common fish population that thus may accumulate negative impacts (Jager, 2010). The increasing concentration of power plants along the Wadden Sea necessitates the adaptation of governance systems to cope with this upscaling and the cumulation of potential negative effects for the ecosystem.

Harbour development along the Wadden Sea and in the estuaries is a second important example illustrating the need to upscale management of the area. In order to cope with the global trend of intensifying trade and port development, there is a need to coordinate an integrated study of port developments in the region, their socio-economic significance and their impact on the ecosystem. This requires a joint trilateral economic and social review of the socio-economic development options in the medium and long term in the Wadden Sea Region, in which the entire Rotterdam/AntwerpHamburg region must be considered, including the option of a joint offshore terminal for the ever larger vessels to avoid further dredging in the estuaries. As was illustrated by the case of the Ems estuary, dredging modifies the hydraulics so that the turbidity in the estuary increases (de Jonge, 1983, 2000). When hydraulics related to the estuarine turbidity zone is strongly modified the system changes into a turbid and (in summer) anoxic state that is excluding migration and reproduction of diadromous fish (Schuttelaars et al., 2011). In estuaries with large harbours (e.g. Elbe, Schelde) different mitigation options are investigated within the TIDE-project (http://tide-project.eu/) but given the extensive and difficult measures to take, it is questionable if such mitigation is possible when harbour development takes place in a distributed and diluted along the entire coast.

Proper trilateral management of the Wadden Sea Region in times of globalisation needs to be nested into a management regime to be developed for the entire North Sea region which in turn constitutes a part of the sustainability policies for the European seas. Conversely, proper management entities within the Wadden Sea are tidal basins and estuaries, islands and mainland counties or municipalities. Scale hierarchies are an important template for organizing management networks. A proper organization of the hierarchy in the management system can make the difference between effective and ineffective management (Cumming et al., 2006; Olsson et al., 2007).

\subsection{Dealing with uncertainty}

Natural systems are variable, both in the external forcing by weather, climate, hydrography, nutrient input etc., as well as in their internal functioning. Our current understanding of the ecology is partial and does not allow to fully predict the system's future state, not even at an integrated and overall level. It is even questionable whether this will ever be possible, given the fundamentally chaotic behaviour of ecological systems (e.g. Huisman and Weissing, 1999). However, an additional level of complexity is added when the external forcing of the system is pushing the system outside its normal range of operation, and moreover key players in the ecosystem are changing due to invasions. Such is the case with the foreseen changes in the coming decades in the Wadden Sea, as discussed before. Especially under these conditions, non-linear threshold behaviour and the occurrence of strong hysteresis may considerably increase the unpredictability of systems. Groffman et al. (2006) discuss the importance of ecological thresholds in coastal management. They tentatively conclude that consideration of thresholds will soon gain in importance. This is certainly true with respect to the discussions on management of the Wadden Sea. Threshold dynamics are central in discussions concerning seagrass restoration (Van der Heide et al., 2007), the response of tidal basins to rapid sea-level rise (Dastgheib et al., 2008; Fruergaard et al., 2010; Madsen et al., 2010; Van Goor et al., 2003), the response of estuarine freshwater reaches to dredging and sediment dynamics (Schuttelaars et al., 2011; Talke and De Swart, 2006). However, it is at present unclear whether these discussions and considerations on threshold dynamics will also fundamentally alter management. The question whether the thresholds can be proven and quantified is very important, because this determines to what degree practical consequences can be drawn from theoretically interesting discussions.

An extremely flat coastal region such as the Wadden Sea is susceptible to minor changes in sea-level. There is little hope that projections on further sea-level rise will soon achieve a level of precision which could allow the planning of proper timing and details for adjustments (Willis and Church, 2012). This uncertainty invites for an attitude of 'wait and see'. However, wrongly underestimating sea-level rise (and thus not taking precautionary measures of coastal defence in advance) and wrongly overestimating the rate of sea-level rise (and thus taking action earlier than would have been necessary) constitute very uneven risks. The former error may cost lives while the latter is an aid to coming generations. Thus, in case of unpredictability on a shorter time scale, management should be based on the (intuitively) most pessimistic scenarios and constantly be prepared to be adjusted in case better predictions become available.

\section{An integrated systems approach for the Wadden Sea system}

From the previous paragraphs on the history of the Wadden Sea system as well as on the future prospects a number of relevant issues and characteristics for the scientific study of this system can 
be derived. These issues should be the core part of recommendations for the further scientific study of the Wadden Sea Region.

One of the most important lessons from the historic overview is that the time scale of human impact is comparable to that of geological and landscape-forming processes (millennium to century scale). It is impossible to envisage how the Wadden Sea would look like in the present day without human influence, because this influence started at a point in time where the external forcing (e.g. sea-level, climate, nutrient availability, sediment availability) was fundamentally different from the current one. Over the last millennium, the landscape has been formed by an interacting system of human and natural forces, with the emphasis slowly shifting towards the human factor. Thus, understanding the landscape formation and evolution of the ecological system without paying attention to this human factor is impossible. Similarly, when thinking about future prospects, it is very important to incorporate essential characteristics of human society, e.g. globalisation of the economy. The latter emphasizes the scale aspect. Obviously, not only human or societal processes vary with the scale of study. It is well known in all sciences that scale is a fundamental issue to both the description of patterns and the understanding of processes.

The role of science in sustainable management of natural heritage sites is complicated. In the Dutch Wadden Sea it has been the subject of study in the context of the cockle fisheries debate (e.g. Hanssen et al., 2009; Runhaar \& van Nieuwaal, 2010; Swart and van Andel, 2008; Turnhout, 2008) and recently reviewed by Floor et al. (in press). Based on the analysis of the latter authors, the case illustrates the prominent role of scientific knowledge in the uprise and solution of societal conflicts. They emphasize that the governance system, by explicitly demanding scientific evidence to make a case, risks putting science itself in the heart of the conflict. Scientists are easily categorized as 'belonging' to one of the parties, which may inhibit the adoption of scientific conclusions by other parties. The possible strategies for scientists are summarized in three types: (1) a strategy where the scientist stresses independence and helps parties resolve a conflict, (2) a strategy in which scientists take an extended accountability and acknowledge their connections with the societal field; (3) a strategy of knowledge coproduction that incorporates multiple perspectives within the process of knowledge production. The strategy influences the effectiveness of the scientific efforts, but often a choice is imposed onto the researchers. Hanssen et al. (2009) distinguish between a facilitation and a pacification role of science. Facilitation attempts to first build consensus on a joint view and ambition before choosing how to use scientific research to decrease uncertainty about the problem. Pacification attempts to solve societal debate by resolving the scientific uncertainty and thereby enforcing the 'most logical' solution. It depends on the nature of the problem which strategy is most efficient. In particular, the level of uncertainty and the degree to which scientific research can reduce this uncertainty in a reasonable time, can guide in the choice between strategies.

Compared to a single case study such as reviewed by Floor et al. (in press), the management of a system as a whole is a much widerranging problem. Olsson et al. (2006) illustrate many possible deadlocks of such a problem. Some are directly related to the organization of scientific knowledge. In particular, the abilities to cross scales, issues and points of view are of great importance, as is the ability to foster discussion without polarization. Although for the solution of particular small-scale problems a one-issue one-scale science approach may be effective at the short term, it is of paramount importance that a broader framework be developed allowing an approach to the social-ecological system from a wide angle.

Based on these considerations, we advocate an integrated systems approach for the scientific study and an adaptive, self- learning and science-based approach to the management of the system. The essence of the approach is that, within the scientific study, different disciplines as well as different scales of study and different points of view are integrated. Moreover, in order to be effective, there should also be a close interaction between scientific study and management. Below we detail what we envisage as the main lines of this approach.

6.1. A combination of more than one scientific discipline, with the emphasis on interactions between the studies of the natural and the socio-economic systems

In Section 2 we have illustrated the close intertwining of natural and human processes in shaping the Wadden Sea system. Also within natural sciences, e.g. between ecology and geomorphology, important cross-disciplinary links should be made. An example that has recently drawn some attention is formed by so-called 'ecosystem engineers' (Jones et al., 1994), organisms that shape their own environment within a given physical context, e.g. saltmarsh plants, mussel and oyster reefs etc. Without proper understanding of the physical context, or without proper understanding of the ecological constraints for the populations, no clear picture of the interaction and its consequences for the system can be found. The possible implications of these organisms for the Wadden Sea are discussed by Eriksson et al. (2010), Olff et al. (2009), Reise and Van Beusekom (2008) and Van der Heide et al. (2007). Further cross-disciplinary links within natural sciences are found in climate science, where many disciplines need to be combined in order to properly predict the response of the system to climate change. A peculiar example of cross-disciplinary interactions, relating back to the similar timescales of geological and historical developments in the area, is provided by palaeographic studies of the old habitation mounds, where geographic, geological, historical and archaeological evidence has to be compared in order to reconstruct both human culture and the natural environment in which it developed.

The development of cross-disciplinary approaches between social, economic and natural sciences is the most demanding task for an integrated approach (see also De Jonge et al., this volume, and references therein). Of course, the applied aspect of many studies underlying management will eventually require some consideration of societal and economic aspects even in natural science studies, but in the Wadden Sea system there are a number of pressing issues where the interaction should go further than this. The study of sustainability of economic development in this valuable and vulnerable landscape poses high demands on the degree of integration between different approaches and disciplines. Despite the principal meaning of the word, 'conservation' policy of natural, as well as cultural (heritage) values cannot simply restrict itself to conserving whatever is present at this moment. The changes in both the natural and human systems will guarantee that such strategy cannot be successful at long term. If it is impossible to conserve the present (or any arbitrarily chosen past) condition, because of changing external conditions, the question arises which future state will be chosen as a target for 'conservation' strategies. As we have illustrated before, this is intimately linked with societal and human values. Humans have shaped the system in the past according to their (changing) values. They are likely to do so in the future too. Understanding the source of these value systems, informing managers and public about the consequences for the natural system with its own feedbacks and constraints, and investigating alternatives that better realise the societal values, is an important aspect of future research in the Wadden Sea. It cannot be realised without proper understanding of both the human mentality, economic endeavours and the close interactions with the natural processes. 


\subsection{Focus on space and time scales}

It is important to make the space and time scales to which processes relate explicit. A few examples: when considering climate change, the spatial scale is what mostly determines the uncertainty of the predictions; it is difficult to make predictions about the global climate but even more so to make them about the climate in the Wadden Sea (Kabat et al., 2009b). An uncertainty analysis based on scale must always be included. In natural development or projects for triggering geomorphological processes, the scale of development measures is often the key to (potential) success. It is thereby important to take into account that the Wadden Sea is an open system, with continuous exchange with the adjacent North Sea which has major consequences for the sediment balance and the ecological production of the Wadden Sea (Postma, 1981; van Beusekom, this volume). There is also the question as to whether we should view maximum diversity of habitats and species on the scale of a basin, the international Wadden Sea or the world. In the trilateral QSR (Marencic and De Vlas, 2009), the scale of the Wadden Sea is used implicitly in most chapters but also national criteria or indicators, e.g. the surface of mussel beds or seagrass beds, are in use in the different nations. Considerations of shared human use can also differ greatly depending on the scale on which the effect of the use is being analysed.

Like the natural Wadden Sea, the social system of the Wadden Sea Region is an open system with ongoing, ever-changing influences of external authorities and with international exchange not only of goods and people but also of ideas; this all is part of the process of globalisation. Regulations and legal frameworks are on a scale of time; interventions must be consistent with current regulations but take account of future developments in both the natural and the socio-economic system. This was illustrated in Section 4 for the port developments in the Wadden Sea Region. Sijtsma et al. (2012, this volume) present a spatial-temporal analysis of tourism in the Dutch part of the Wadden Sea Region and identify the related policy dilemmas.

Scale match and mismatch between 'ecological' (natural) and social systems is a promising analytical approach to the organization of governance systems (Cumming et al., 2006). The underlying concept is that both natural and governance systems have hierarchies of typical temporal and spatial scales that dominate (important parts of) their behaviour. When the scales of management mismatch with the scales of the ecological and geological processes or natural resources being managed, problems arise that should be solved by properly re-matching the scales. Scale mismatches occur when the governance system operates at too broad a scale (one measure fits all) while the natural system behaves fundamentally different at smaller scales. Reversely, micromanagement of phenomena operating at much larger scales also results in a scale mismatch.

In the Wadden Sea, the management of harbours and industrial facilities at present may be an example of micromanagement bias. Following a global trend, there is a parallel development along the entire coast and in all estuaries connected to the Wadden Sea of construction of power plants, dredging operations and harbour expansion. Little national, let alone international coordination of these developments takes place, yet they are influencing the same populations of biota and the same set of geomorphological processes. Adjusting governance scale in this example will not be an easy task, and should probably be guided by scientific exploration of the case. Examples of macromanagement bias may be in nutrient management, where clear differences at relatively small scales seem to exist in nutrient concentrations and fluxes (van Beusekom et al., 2009) and eutrophication-oligotrophication phenomena may be differentiated at smaller scale than previously thought. However, better study of these phenomena is needed before precautionary management could be reviewed.
What constitutes 'the' scale of the system is itself the subject of societal debate, and even of 'politics of scale' (Lebel et al., 2005). Larsen (2008) discusses this with respect to the 'creation' of the Baltic as one system of management. Although a fair degree of political arbitrariness and opportunism is involved in the choice of this fundamental system, it is clearly an advantage when this choice coincides with a dominant scale in the natural system, i.e. if the system chosen operates as a relatively homogeneous and independent subsystem and is therefore responding as a unit to the management.

For the Wadden Sea, both the geography of the area and the governance structure show the complexity of the multitude of scales in the natural and the social systems. Scientific studies should take this multitude of scales into account. Studies performed in a single tidal basin, e.g. oligotrophication in the Western Dutch Wadden Sea (Philippart et al., 2007), are not necessarily equally valid in other parts of the Dutch, let alone the international Wadden Sea (Eriksson et al., 2010). Comparison of different tidal basins along the entire Wadden Sea, was well as detailed studies within each of these basins, should permit to complete our image of the exchanges and spatial differentiation. This is not only true for ecological studies, but applies to geomorphology as well.

\subsection{Focus on the accumulation of processes}

Observing a single process/subsystem/intervention in isolation can produce a completely different picture than when it is observed in conjunction with other interventions and processes. Cumulative impacts of human interventions in the system must be explicitly taken into account in current legal frameworks but this poses serious problems in practice. The problems arise primarily because of unexpected interactions between processes of very different nature.

Adapting our coastal protection of the low-lying land to a possible future of increased rate of sea-level rise will be a complex of problems that will require multidisciplinary approaches and due consideration of (even unexpected) consequences elsewhere in the system. In principle, with sea-level rise a barrier system tends to react by moving the islands inshore. This is a natural geomorphological development that is well described (Chang et al., 2006). If this is not possible, because of habitation, an alternative source of sand must be found for the tidal basins and the mainland coastal protection. This sand can be supplied at different places, but the ecological and geomorphological consequences of such sand supply are complex, and evaluations need to consider different scales in space and time. Furthermore, supplying sand from offshore sources to balance inshore deficiencies may be incompatible with the deepening of estuarine channels for shipping. This could fundamentally change strategies of ports located in the upper reaches of estuaries such as Hamburg, Emden, Delfzijl and large shipyards like the one in Papenburg (Ems estuary) nearly $100 \mathrm{~km}$ upstream from the tidal inlet. Port activities might be moved to offshore terminals to transfer cargo there from large vessels to small feeders which then commute between terminals and ports.

\subsection{The organisation of integrated science}

When formulating questions and hypotheses, finding answers to the questions and translating knowledge into practical applications, many researchers from the fields of policymaking and fundamental and applied science should be engaged in constantly iterating issues, limiting uncertainty and applying new insights. This aspect is an essential component of an integrated approach.

We have to evaluate if the existing structures of the science world are suitable to support interdisciplinary science. Interdisciplinary research projects for the above-mentioned examples might 


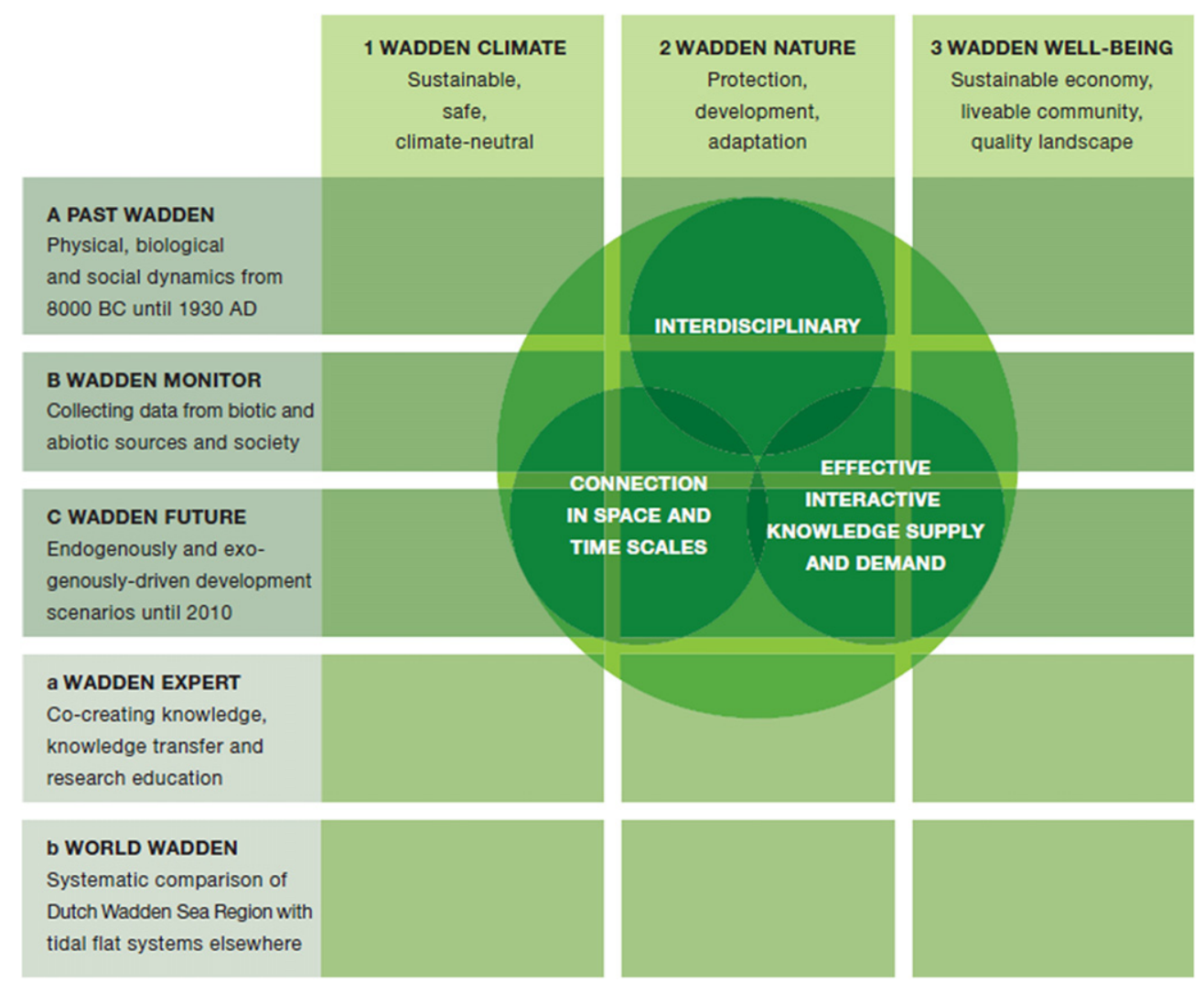

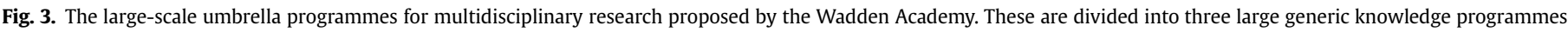

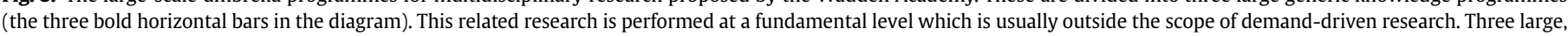

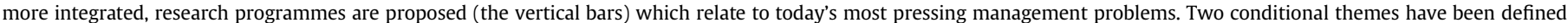

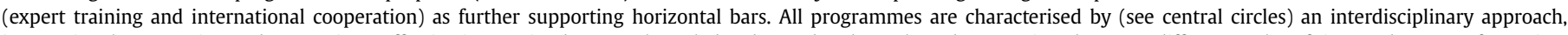

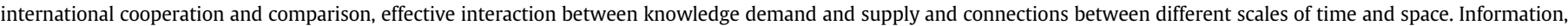
data, knowledge and expertise are exchanged at the interface between the horizontal and vertical programmes. Source: Kabat et al., 2009a.

be relatively easy to realise by bringing together scientists of different disciplines in a specific project. In the research agenda of the Wadden Academy (Kabat et al., 2009a) umbrella programmes are described (see Fig. 3) which should guarantee the integrated nature of science in the Dutch part of the Wadden Sea Region. An effort is made to promote the international exchange of data and information at the trilateral level.

To further support the required level of integrality and system thinking in research in the Wadden Sea Region, studies are needed that focus on the understanding of the combined 'ecological' and socio-economic (valuation) system of the whole Wadden Sea Region (see also De Jonge et al, this volume). Ideally, this system thinking will provide a framework in which knowledge is integrated for management purposes. This calls for a reorganisation of science where the position of scientists that develop concepts, models and decision support systems to connect interdisciplinary research and management becomes much more visible. A structure is needed where this specific group of scientists interacts with both 'monodisciplinary' scientists, the public and policymakers. In addition it will be necessary to invest heavily in the creation of a new generation of 'Wadden Sea scientists' that are able to convey novel approaches to the general public and to design science-based management support systems.

\section{Ethical statement}

Our paper is original work not published or submitted elsewhere (except for parts published under our own name in reports referred to in the text). We furthermore have kept to all other author standards, concerning Acknowledgement of Sources, Authorship of the Paper, Hazards for Human or Animal Subjects, Disclosure and Conflicts of Interest.

\section{Acknowledgements}

We thank Prof. Victor de Jonge for challenging criticism and Prof. Franciscus Colijn and two anonymous reviewers.

\section{References}

Aagaard, T., Nielsen, N., Nielsen, J., 1995. Skallingen - origin and evolution of a barrier spit. Med. From Skalling Laboratory 35, 86

Abrahamse, J., Joenje, W., Van Leeuwen Seelt, N. (Eds.), 1976. Waddenzee. Natuurgebied van Nederland, Duitsland en Denemarken. Waddenvereniging, Harlingen. also in German: Wachholtz, Neumünster.

Bakker, J.A., 2011. Paalwormen, dijken, hunebedden en onze eerste monumentenwet. Van graven in de prehistorie en dingen die voorbijgaan. Studies aangeboden aan Eric Lohof bij zijn pensionering in de archeologie, 281-324.

Bantelmann, A., 1992. Landschaft und Besiedlung Nordfrieslands in vorgeschichtlicher Zeit. Schriftenreihe Dr.-Carl-Haeberlin-Friesenmuseum Wyk auf Föhr, N.F 9, 48.

Bartholdy, J., Pejrup, M., 1994. Holocene evolution of the Danish Wadden Sea. Senckenbergiana Maritima 24, 187-209.

Bazelmans, J., Meier, D., Nieuwhof, A., Spek, T., Vos, P. Understanding the cultural historical value of the Wadden Sea region. The co-evolution of environment and society in the Wadden Sea area in the Holocene up until early modern times (11,700 BC-1800 AD): an outline. Ocean and Coastal Management, in this volume.

Behre, K.-E., 2008. Landschaftsgeschichte Norddeutschlands. Wacholtz, Neumünster, 307. 
Beukema, J.J., 1992. Expected changes in the Wadden Sea benthos in a warmer world: lessons from periods with mild winters. Netherlands Journal of Sea Research 30, 73-79.

Beukema, J.J., Dekker, R., 2005. Decline of recruitment success in cockles and other bivalves in the Wadden Sea: possible role of climate change, predation on postlarvae and fisheries, Marine Ecology Progress Series 287, 149-167.

Beukema, J.J., Dekker, R., 2011. Increasing species richness of the macrozoobenthic fauna on tidal flats of the Wadden Sea by local range expansion and invasion of exotic species. Helgoland Marine Research 65, 155-164.

Beukema, J.J., Wolff, W.J., Brouns, J.J.W.M. (Eds.), 1990. Expected Effects of Climatic Change on Marine Coastal Ecosystems. Kluwer Acad. Publ., Dordrecht, p. 221.

Beukema, J.J., Dekker, R., Jansen, J.M., 2009. Some like it cold: populations of the tellinid bivalve Macoma balthica (L.) suffer in various ways from a warming climate. Marine Ecology Progress Series 384, 135-145.

Buschbaum, C., Lackschewitz, D., Reise, K. Nonnative macrobenthos in the Wadden Sea ecosystem. Ocean and Coastal Management, in this volume.

Carroll, S.P., 2011. Conciliation biology: the eco-evolutionary management of permanently invaded biotic systems. Evolutionary Applications 4, 184-199.

Carson, R., 1962. Silent Spring. Houghton Mifflin, 368 pp.

Chang, T.S., Flemming, B.W., Tilch, E., Bartholomae, A., Woestmann, R., 2006. Late Holocene stratigraphic evolution of a back-barrier tidal basin in the East Frisian Wadden Sea, southern North Sea: transgressive deposition and its preservation potential. Facies 52, 329-340.

CPSL, 2010. Coastal protection and sea-level rise. Third Report. Wadden Sea Ecosystem. In: Working Group on Coastal Protection and Sea Level Rise, vol. 28. Common Wadden Sea Secretariat, Wilhelmshaven, Germany, pp. 1-51.

Cumming, G.S., Cumming, D.H.M., Redman, C.L., 2006. Scale mismatches in social-ecological systems: causes, consequences, and solutions. Ecology and Society 11 (1). Article Number: 14.

CWSS, 1998. Stade Declaration. Trilateral Wadden Sea Plan. Common Wadden Sea Secretariat, Wilhelmshaven, $110 \mathrm{pp}$.

CWSS, 2008. Nomination of the Dutch-German Wadden Sea as a world heritage site. In: World Heritage Nomination Project Group, Wadden Sea Ecosystem, vol. 24. Common Wadden Sea Secretariat, Wilhelmshaven, Germany. 1-200.

CWSS, 2010. Wadden Sea Plan 2010. Common Wadden Sea Secretariat, Wilhelmshaven, Germany, 88 pp. www.waddensea-secretariat.org.

Dastgheib, A., Roelvink, J.A., Wang, Z.B., 2008. Long-term process-based morphological modeling of the Marsdiep tidal basin. Marine Geology 256, 90-100. http://dx.doi.org/10.1016/j.margeo.2008.10.003.

De Beaufort, L.F., 1954. Veranderingen in de flora en fauna van de Zuiderzee (thans IJsselmeer) na de afsluiting in 1932. De Boer Publ., Den Helder, 359 pp.

De Jonge, V.N., 1983. Relations between annual dredging activities, suspended matter concentrations, and the development of the tidal regime in the Ems estuary. Canadian Journal of Fish and Aquatic Science 40 (Suppl. 1), 289-300.

De Jonge, V.N., 2000. Importance of temporal and spatial scales in applying biological and physical process knowledge in coastal management, an example for the Ems estuary. Continental Shelf Research 20, 1655-1686.

De Jonge, V.N., 2009. From a defensive to an integrated approach. In: Reinhard, S., Folmer, H. (Eds.), Water Policy in the Netherlands. Integrated Management in a Densely Populated Area. RFF Press, Washington.

De Jonge, V.N., Pinto, R., Turner, R.K. Integrating ecological, economic and social aspects to generate useful management information under the EU Directives' 'Ecosystem Approach'. Ocean and Coastal Management, in this volume.

De Mulder, E.F.J., Geluk, M.C., Ritsema, I.L., Westerhoff, W.E., Wong, T.E., 2003. De ondergrond van Nederland. Wolters Noordhoff, 379.

Diederich, S., Nehls, G., Van Beusekom, J.E.E., Reise, K., 2005. Introduced Pacific oysters (Crassostrea gigas) in the northern Wadden Sea: invasion accelerated by warm summers? Helgoland Marine Research 59, 97-106.

Eriksson, B.K., van der Heide, T., van de Koppel, J., Piersma, T., van der Veer, H.W., Olff, H., 2010. Major changes in the ecology of the Wadden Sea: human impacts, ecosystem engineering and sediment dynamics. Ecosystem 13 (5), 752-764. http://dx.doi.org/10.1007/s10021-010-9352-3.

Eurostat, 2012. http://epp.eurostat.ec.europa.eu/statistics_explained/index.php/ Maritime_ports_freight_and_passenger_statistics. accessed 7/5/2012.

Fischer, L., 2011. Küste - Von der Realität eines mentalen Konzepts. In: Fischer, L, Reise, K. (Eds.), Küstenmentalität und Klimawandel. Oekom, München, pp. $31-53$.

FitzGerald, D.M., Fenster, M.S., Buynevich, I.V., Argow, B.A., 2008. Coastal impacts due to sea-level rise. Annual Review of Earth and Planetary Sciences 36, 601-647.

Floor, J.R., Van Koppen, C.S.A., Lindeboom, H. Review of Science-policy Interactions in the Dutch Wadden Sea - The Cockle Fishery and Gas Exploitation Controversies, submitted for publication.

Fruergaard, M., Andersen, T.J., Nielsen, L.H., Madsen, A.T., Johannessen, P.N., Murray, A.S., Kirkegaard, L., Pejrup, M., 2010. Punctuated sediment record resulting from channel migration in a shallow sand-dominated micro-tidal lagoon, Northern Wadden Sea, Denmark. Marine Geology 280, 91-104.

Gaffney, V., Fitch, S., Smith, D., 2009. Europe's Lost World. The Rediscovery of Doggerland. Res. Rep. 160. Council British Archaeology, York, 202 pp.

Gehrels, W.R., Szkornik, K., Bartholdy, J., Kirby, J.R., Bradley, S.L., Marshall, W.A. Heinemeier, J., Pedersen, J.B.T., 2006. Late Holocene sea-level changes and isostasy in western Denmark. Quaternary Research 66, 288-302.

Groffman, P.M., Baron, J.S., Blett, T., Gold, A.J., Goodman, I., Gunderson, L.H., Levinson, B.M., Palmer, M.A., Paerl, H.W., Peterson, G.D., Poff, N.L., Rejeski, D.W. Reynolds, J.F., Turner, M.G., Weathers, K.C., Wiens, J., 2006. Ecological thresholds: the key to successful environmental management or an important concept with no practical application? Ecosystems 9, 1-13.

Hanssen, L., Rouwette, E., van Katwijk, M., 2009. The role of ecological science in environmental policy-making: from a pacification towards a facilitation strategy. Ecology and Society 14 (1). article $\mathrm{nr} 43$.

Huisman, J., Weissing, F.J., 1999. Biodiversity of plankton by species oscillations and chaos. Nature 402, 407-410. doi:10.1038/46540.

IPCC, 2007. Climate Change 2007. Fourth Assessment Report (AR4) of the United Nations Intergovernmental Panel on Climate Change. www.ipcc.ch.

Jager, Z., 2010. Position Paper on the Sustainable Use of Cooling Water from the Wadden Sea. Waddenacademie report 2010-3. http://www.waddenacademie. nl/fileadmin/inhoud/pdf/02_taken/kennisagendarapporten/2010-03_Position paper on the sustainable use of cooling water from the Wadden Sea.pdf.

Jakubowski-Tiessen, M., 2011. Vom Umgang mit dem Meer: Sturmfluten und Deichbau als mentale Herausforderung. In: Fischer, L., Reise, K. (Eds.), Küstenmentalität und Klimawandel. Oekom, München, pp. 55-64.

Jones, C.G., Lawton, J.H., Shachak, M., 1994. Organisms as ecosystem engineers. Oikos 69, 373-386

Kabat, P., Bazelmans, J., van Dijk, J., Herman, P.M.J., Speelman, H., Deen, N.R.J., Hutjes, R.W.A. (Eds.) 2009a. Knowledge for a Sustainable Future of the Wadden - Integrated Research Agenda of the Wadden Academy. Wadden Academy-KNAW. Leeuwarden, The Netherlands.

Kabat, P., Jacobs, C.M.J., Hutjes, R.W.A., Hazeleger, W., Engelmoer, M., Witte, J.P.M Roggema, R., Lammerts, E.J., Bessembinder, J., Hoekstra, P., van den Berg, M. 2009b. Klimaatverandering en het Waddengebied. Position paper Klimaat en Water. Wadden Academy-KNAW, Leeuwarden, The Netherlands.

Kemp, A.C. Horton, B.P., Donnelly, J.P., Mann, M.E., Vermeer, M., Rahmstorf, S., 2011 Climate related sea-level variations over the past two millennia. Proc. Nat. Acad. Sci. (PNAS) 108, 11017-11022.

Knottnerus, O.S., 2005. History of human settlement, cultural change and interference with the marine environment. Helgoland Marine Research 59, $2-8$

Larsen, H.G., 2008. Scaling the Baltic Sea environment. Geoforum 39, 2000-2008.

Latour, B., 2004. Politics of Nature: How to Bring the Sciences into Democracy. Harvard University Press.

Lebel, L., Garden, P., Imamura, M., 2005. The politics of scale, position, and place in the governance of water resources in the Mekong region. Ecology and Society 10 (2), 18. http://www.ecologyandsociety.org/vol10/iss2/art18/.

Loebl, M., Beusekom, J.E.E., van, Reise, K., 2006. Is spread of the neophyte Spartina anglica recently enhanced by increasing temperatures? Aquatic Ecology 40 315-324

Lotze, H.K., Reise, K., Worm, B., Van Beusekom, J., Busch, M., Ehlers, A., Heinrich, D. Hoffmann, R.C., Holm, P., Jensen, C., Knottnerus, O.S., Langhanki, N., Prummel, W., Vollmer, M., Wolff, W.J., 2005. Human transformations of the Wadden Sea ecosystem through time: a synthesis. Helgoland Marine Research 59, 84-95.

Madsen, A.T., Murray, A.S., Andersen, T.J., Pejrup, M., 2010. Spatial and temporal variability of sediment accumulation rates on two tidal flats in Lister Dyb tida basin, Wadden Sea. Denmark: Earth Surface Processes and Landforms 35 , 1556-1572.

Marencic, H., De Vlas, J. (Eds.), 2009. Quality Status Report 2009. Wadden Sea Ecosystem, vol. 25. Common Wadden Sea Secretariat, Trilateral Monitoring and Assessment Group, Wilhelmshaven, Germany.

Nehls, G., Diederich, S., Thieltges, D.W., Strasser, M., 2006. Wadden Sea mussel beds invaded by oysters and slipper limpets: competition or climate control? Helgoland Marine Research 60, 135-143.

Olff, H., Alonso, D., Berg, M.P., Eriksson, B.K., Loreau, M., Piersma, T., Rooney, N., 2009. Parallel ecological networks in ecosystems. Philosophical Transactions of Royal Society B 364, 1755-1779.

Olsson, P., Gunderson, L.H., Carpenter, S.R., Ryan, P., Lebel, L., Folke, C., Holling, C.S. 2006. Shooting the rapids: navigating transitions to adaptive governance of social-ecological systems. Ecology and Society 11 (1), 18. http://www. ecologyandsociety.org/vol11/iss1/art18/.

Olsson, P., Folke, C., Galaz, V., Hahn, T., Schultz, L., 2007. Enhancing the fit through adaptive comanagement: creating and maintaining bridging functions for matching scales in the Kristianstads Vattenrike Biosphere Reserve Sweden. Ecology and Society 12 (1), 28. http://www.ecologyandsociety.org/vol12/iss1/ art28/.

Oost A.P. 1995. Dynamics and Sedimentary Development of the Dutch Wadden Sea with Emphasis on the Frisian Inlet. In: Geologica Ultraiectina, vol. 126. Utrecht University, $455 \mathrm{p}$

Oosterhaven, J., 1981. Interregional Input-Output Analysis and Dutch Regional Policy Problems. Gower Publishing, Aldershot-Hampshire.

Philippart, C.J.M., Epping, H.G., 2009. The Wadden Sea: a coastal ecosystem under continuous change. In: Kennish, M.J., Paerl, H.W. (Eds.), Coastal Lagoons: Critical Habitats of Environmental Change. CRC Press - Marine Science Book Series, 568 p.

Philippart, C.J.M., Beukema, J.J., Cadée, G.C., Dekker, R., Goedhart, P.W., van Iperen, J.M., Leopold, M.F., Herman, P.M.J., 2007. Impacts of nutrient reduction on coastal communities. Ecosystems 10, 96-119.

Piersma, T., Koolhaas, A., Dekinga, A., Beukema, J.J., Dekker, R., Essink, K., 2001. Long-term indirect effects of mechanical cockle-dredging on intertidal bivalve stocks in the Wadden Sea. Journal of Applied Ecology 38, 976-990.

Postma, H., 1981. Exchange of materials between the North Sea and the Wadden Sea. Marine Geology 40, 199-215. 
Reise, K., 2003. More sand to the shorelines of the Wadden Sea. Harmonizing coastal defense with habitat dynamics. In: Wefer, G., Lamy, F., Mantoura, F. (Eds.), Marine Science Frontiers of Europe. Springer, Berlin Heidelberg New York, pp. 203-216.

Reise, K., 2005. Coast of change: habitat loss and transformations in the Wadden Sea. Helgoland Marine Research 59, 9-21.

Reise, K., 2011. Das Wattenmeer - Wirklichkeiten und Visionen. In: Fischer, L., Reise, K. (Eds.), Küstenmentalität und Klimawandel. Oekom, München, pp. 167-179.

Reise, K., van Beusekom, J.E.E., 2008. Interactive effects of global and regional change on a coastal ecosystem. Helgoland Marine Research 62, 85-91.

Reise, K., Baptist, M., Burbridge, P., Dankers, N., Fischer, L., Flemming, B., Oost, A.P., Smit, C., 2010. No. The Wadden Sea - A Universally Outstanding Tidal Wetland. Wadden Sea Ecosystem, vol. 29. Common Wadden Sea Secretariat, Wilhelmshaven, Germany. 7-24.

Runhaar, H., Van Nieuwaal, K., 2010. Understanding the use of science in decisionmaking on cockle fisheries and gas exploitation in the Dutch Wadden Sea: putting the science-policy interface in a wider perspective. Environmental Science \& Policy 13, 239-248.

Runhaar, H., Runhaar, P.R., Oegema, T., 2009. Food for thought: conditions for discourse reflection in the light of environmental assessment. Environ Impact Asses Review. http://dx.doi.org/10.1016/j.eiar.2009.12.001.

Samen werken met water, 2008. Deltacommissie (Ed). 136 pp. ISBN 978-909023484-7. http://www.deltacommissie.com/doc/2008-09-03\%20Advies\% 20Deltacommissie.pdf.

Schuttelaars, H., De Jonge, V.N., Chernetsky, A., 2011. Influence of the length of an estuary on tidal motion and sediment trapping. Report for WWF 29.

Sijtsma, F.J., Hoekstra, H., Werner, G., Daams, M., Broersma, L. Tourism in the Dutch Waddenarea: A Spatial-temporal Analysis Identifying Policy Dilemma's, in this volume.

Streif, H., 2004. Sedimentary record of Pleistocene and Holocene marine inundations along the North Sea coast of lower Saxony, Germany. Quaternary International $112,3-28$.

Swart, J.A.A., Van Andel, J., 2008. Rethinking the interface between ecology and society. The case of the cockle controversy in the Dutch Wadden Sea. Journal of Applied Ecology 45, 82-90.

Talke, S.A., de Swart, H.E., 2006. Hydrodynamics and Morphology in the Ems/Dollard Estuary: Review of Models, Measurements, Scientific Literature, and the Effects of Changing Conditions. Report for Rijkswaterstaat, vol. 78. Ministry of Public Works, Netherlands.

Turnhout, E., 2008. Science in Wadden Sea policy: from accommodation to advocacy. Environmental Science \& Policy 11, 227-239.

UNESCO, 2009. World Heritage Committee Decision. 33 COM 8B.4. http://whc. unesco.org/en/decisions/1946/.

Van Beusekom, J.E.E., Bot, P.V.M., Carstensen, J., Goebel, J.H.M., Lenhart, H., Pätsch, J, Petenati, T., Raabe, T., Reise, K., Wetsteijn, B., 2009. Eutrophication. In: Marencic, H., De Vlas, J. (Eds.), 2009. Quality Status Report 2009. Wadden Sea Ecosystem, vol. 25. Common Wadden Sea Secretariat, Trilateral Monitoring and Assessment Group, Wilhelmshaven, Germany.

Van Beusekom, J.E.E., Buschbaum, C., Reise, K. Towards understanding regional differences in Wadden Sea Ecology: The North Sea underestimated? Ocean Coastal Management, in this volume.

Van der Aa, B.J.M., Groote, P.D., Huigen, P.P.P., 2004. World heritage as NIMBY? The case of the Dutch part of the Wadden sea. Current Issues in Tourism 7 (4-5), 291-302.

Van der Heide, T., van Nes, E.H., Geerling, G.W., Smolders, A.J.P., Bouma, T.J., van Katwijk, M.M., 2007. Positive feedbacks in seagrass ecosystems: Implications for success in conservation and restoration. Ecosystems 10 (8), 1311-1322. http:// dx.doi.org/10.1007/s10021-007-9099-7.

Van der Meer, W., 2009. Harvesting underwater meadows, use of eelgrass (Zoster spp.) as indicated by the Dutch archaeological record. Journal of Archaeology of the Low Countries 1-1. http://dpc.uba.uva.nl/jalc/01/nr01/a06.
Van der Spek, A.J.F., Beets, D.J., 1992. Mid-Holocene evolution of a tidal basin in the western Netherlands: a model for future changes in the northern Netherlands under conditions of accelerateed sea-level rise? Sedimentary Geology 80,185-197.

Van Goor, M.A., Zitman, J.T., Wang, Z.B., Stive, M.J.F., 2003. Impact of sea-level rise on the morphological equilibrium state of tidal inlets. Marine Geology 202, 211-227.

Van Katwijk, M.M., 2003. Reintroduction of eelgrass (Zostera Marina) in the Dutch Wadden sea: a research overview and management vision. In: Wolff, W.J., Essink, k., Kellermann, A., Van Leeuwe, M.A. (eds) Proceedings of the 10th international scientific Wadden Sea symposium, Groningen, The Netherlands, 31 October - 3 November 2000, pp. 173-195.

Van Nieuwaal, K., 2011. The institutional survival path. A case study on mechanical cockle fishery and gas extraction in the Dutch Wadden Sea. Phd Thesis, Vrije Universiteit Amsterdam. 296 pp

Van Veen, J., 1936. Onderzoekingen in de Hoofden in verband met de gesteldheid der Nederlandsche Kust. 's Gravenhage. Algemeene Landsdrukkerij, 252.

Vink, A., Steffen, H., Reinhardt, L., Kaufmann, G., 2007. Holocene relative sea-level change, isostatic subsidence and the radial viscosity structure of the mantle of northwest Europe (Belgium, the Netherlands, Germany, southern North Sea). Quaternary Science Reviews 26, 3249-3275.

Vollmer, M., Guldberg, M., Maluck, M., Marrewijk, D., Schlicksbier, G., 2001. Landscape and cultural heritage in the Wadden sea region- project report. In: Wadden Sea Ecosystem, vol. 12. Common Wadden Sea Secretariat, Trilateral Monitoring and Assessment Group, Wilhelmshaven, Germany.

Von Storch, H., Claussen, M., 2011. Klimabericht für die Metropolregion Hamburg. Springer-Verlag, Berlin, Heidelberg, p. 1-312.

Vos, P.C., van Kesteren, W.P., 2000. The long-term evolution of intertidal mudflats in the northern Netherlands during the Holocene; natural and anthropogenic processes. Continental Shelf Research 20, 1687-1710.

Waddenzeecommissie (commissie Mazure), 1974. Rapport van de Waddenzeecommissie. Advies inzake de voor- en nadelen van inpolderingen in de Waddenzee. Den Haag, mei.

Wahl, T., Jensen, J., Frank, T., Haigh, I.D., 2011. Improved estimates of mean sea level changes in the German Bight over the last 166 years. Ocean Dynamics 61, 701-715.

Wiersma, A.P., Oost, A.P., Van der Berg, M.W., Vos, P.C., Marges, V., De Vries, S., 2009. Thematic Report No. 9: Geomorphology. In: Wadden Sea Ecosystem, vol. 25. Common Wadden Sea Secretariat, Wilhelmshaven, Germany.

Willis, J.K., Church, J.A., 2012. Regional sea-level projection. Science 336, 550-551.

Wiltshire, K.H., Kraberg, A., Bartsch, I., Boersma, M., Franke, H.-D., Freund, J., Gebühr, C., Gerdts, G., Stockmann, K., Wichels, A., 2010. Helgoland Roads, North Sea: 45 years of change. Estuaries and Coasts 33, 295-310.

Witte, S., Buschbaum, C., Beusekom, J.E.E., van, Reise, K., 2010. Does climatic warming explain why an introduced barnacle finally takes over after a lag of more than 50 years? Biological Invasions 12, 3579-3589.

Wolff, W.J., 1976. Introduction to the subject and goal of the conference of Wadden Sea experts. Staatsuitgeverij, 's Gravenhage. In: Wolff, W.J. (Ed.), Proceedings of the Conference of Wadden Sea Experts, Schiermonnikoog, The Netherlands, 26/ 28 November 1975, pp. 29-33.

Wolff, W.J. (Ed.), 1983. Ecology of the Wadden Sea. A.A. Balkema, Rotterdam, ca, p. 2000.

Wolff, W.J., 1992. The end of a tradition: 1000 years of reclamation of wetlands in The Netherlands come to an end. Ambio 21, 287-291.

Wolff, W.J., 2000. Causes of extirpations in the Wadden Sea, an estuarine area in The Netherlands. Conservation Biology 14, 876-885.

Wolff, W.J., 2005. Non-indigenous Marine and Estuarine Species in The Netherlands, vol. 79. Zoölogische Mededelingen, Leiden. 1-116.

Wolff, W.J., Bakker, J., Laursen, K., Reise, K., 2010. The Wadden Sea Quality Status Report - Synthesis Report 2010. Wadden Sea Ecosystem 29. Common Wadden Sea Secretariat, Wilhelmshaven, Germany. 25-74. 